\title{
Ultrasonic shears and bipolar vessel-sealing system for three-port laparoscopic ovariohysterectomy in dogs
}

[Bisturi ultrassônico e sistema de selamento de vasos sanguíneos para ovário-histerectomia laparoscópica com três portais em cães]

\author{
N. Guizzo-Júnior ${ }^{1}$, J.P.S. Feranti ${ }^{2}$, M.C. Bairros ${ }^{1}$, M. Bortoluzzi ${ }^{1}$, A.C. Motta ${ }^{3}$, L.W. Sartori ${ }^{1}$, \\ F.R. Santos ${ }^{4}$, F.V. Tomazzoni ${ }^{1}$, G. Brambatti ${ }^{4}$, R.L. Guedes ${ }^{1}$, M.A.M. Silva ${ }^{3}$, M.V. Brun ${ }^{2 *}$ \\ ${ }^{1}$ Veterinários autônomos - Passo Fundo, RS \\ ${ }^{2}$ Centro de Ciências Rurais - Universidade Federal de Santa Maria - CCR-UFSM - Santa Maria, RS \\ ${ }^{3}$ Universidade de Passo Fundo - UPF - Passo Fundo, RS \\ ${ }^{4}$ Universidade Federal do Rio Grande do Sul - UFRGS - Porto Alegre, RS
}

\begin{abstract}
In the current experimental study, two different instruments were compared for prophylactic hemostasis during a 3-port technique of laparoscopic ovariohysterectomy $(\mathrm{OVH})$ in bitches. Moreover, the need for port enlargement for specimen retrieval using $5 \mathrm{~mm}$ or $10 \mathrm{~mm}$ trocartes, technical difficulties and complications were assessed. Ultrasonic energy and a vascular sealing system were tested. Duration of surgery, patient weight and diameter of the uterine arteries and veins were compared among the groups. Fifteen dogs randomly divided into three groups (GI, GII, GIII) were submitted to ovariohysterectomy with hemostasis from the use of ultrasonic scalpel or vascular sealing equipment. In GI and GII the LigaSure $^{\text {TM }}$ impedance-controlled bipolar vessel-sealing device was used, differing in the size of trocartes used between groups, and in GIII Autosonix ${ }^{\mathrm{TM}}$ was used. Patients' weight, duration of surgery, technical difficulties and complications were compared among the groups. Statistical analysis showed no difference between the data analyzed among the groups. In conclusion, both methods of hemostasis were effective for 3-port total laparoscopic ovariohysterectomy in bitches. However, $5 \mathrm{~mm}$ trocartes were not adequate for retrieval of the uterus and ovaries without need for enlargement of the port incision.
\end{abstract}

Keywords: laparoscopy, canines, coagulation systems, spay, surgery

\section{RESUMO}

No presente experimento, foram comparados dois diferentes equipamentos, um com emprego de energia ultrassônica, e outro utilizando sistema de selamento vascular, como única forma de hemostasia em ovário-histerectomias laparoscópicas com três portais em cadelas. Ademais, a necessidade de ampliação da incisão do portal de $5 \mathrm{~mm}$ ou de $10 \mathrm{~mm}$ para a remoção dos espécimes ressecados, dificuldades técnicas e complicações foram avaliadas. Quinze cadelas aleatoriamente distribuídas em três grupos (GI, GII, GIII) foram submetidas à ovário-histerectomia com hemostasia a partir da utilização de bisturi ultrassônico ou equipamento de selamento vascular. Nos GI e GII foi utilizado um sistema de selamento vascular eletrotérmico bipolar (LigaSure ${ }^{\circledR}$ ), diferindo-se no tamanho dos portais utilizados; em GIII foi utilizado bisturi ultrassônico (Autosonix ${ }^{\circledR}$ ). A análise estatística não demonstrou diferença significativa entre os dados analisados nos três grupos. Conclui-se que ambos os métodos de hemostasia utilizados mostraram-se adequados e viabilizaram a realização de ovário-histerectomia laparoscópica em cadelas. Todavia, o trocarte de $5 \mathrm{~mm}$ não foi adequado para remoção do útero e ovários sem necessidade de ampliação da incisão de acesso.

Palavras-chave: laparoscopia, caninos, sistemas de coagulação, castração, cirurgia

Recebido em 10 de março de 2014

Aceito em 21 de agosto de 2014

*Autor para correspondência (corresponding author)

E-mail: silvamam@gmail.com 


\section{INTRODUCTION}

Minimally invasive laparoscopic surgery (MILS) has changed the traditional concept of surgery in Human Medicine, not as a substitute for conventional techniques, but as a modern surgical and diagnostic tool. MILS offers many advantages in terms of diagnostic and therapeutic approaches (Malm et al., 2004; Howe, 2006). Currently, endoscopic techniques have been increasingly used in veterinary patients, especially for dog spay (Brun et al., 2000; Austin et al., 2003; Hancock et al., 2005; Mayhew et al., 2007).

Maneuvers such as traction, electrocoagulation of the ovarian pedicles and uterine ligaments/vessels and application of extracorporal ligatures require adequate training and may affect surgical time (Malm et al., 2004; Silva et al., 2011). Mean surgical time may be similar (Devitt et al., 2005) or longer (Malm et al., 2004; Hancock et al., 2005) using the laparoscopic approach, while intra-operative bleeding and post-operative pain is usually reduced in comparison to the conventional technique of ovariohysterectomy (OVH) (Hancock et al., 2005; Devitt et al., 2005).

The use of monopolar or bipolar diathermy for prophylactic hemostasis may damage the surrounding tissues and be less effective to seal the vessels in comparison to ultrasonic energy or vascular clips (Bubenik et al., 2005; Mayhew and Brown, 2007).

Therefore, the aim of the current study was to compare the effectiveness, complications and technical difficulties of the use of the ultrasonic shears and the modulated bipolar vessel-sealing system on the prophylactic hemostasis of the vessels during a 3-port laparoscopic approach for $\mathrm{OVH}$ in bitches, and to assess the need for port enlargement for uterine and ovary retrieval using $5 \mathrm{~mm}$ or $10 \mathrm{~mm}$ trocarte.

\section{MATERIALS AND METHODS}

The current research was approved by the Committee of Ethics in Research of the University of Passo Fundo (CEP-UPF, protocol number 047/2008). Fifteen healthy mixed-breed bitches, body weight ranging from 6 to $18.9 \mathrm{~kg}$, were assessed. The dogs belonged to a private shelter, and were adopted at the end of the study. The animals were examined clinically and blood analyses were carried out, which were exclusion criteria in order to join the study. The patients were placed in individual kennels and fed adequate commercial dog food and water ad libitum up to 12 hours prior to surgery.

The bitches were operated on by a single surgical team, which was at the beginning of the learning curve for laparoscopic spay techniques. The animals were randomly placed into three experimental groups, varying according to the method of prophylactic hemostasis and port size for specimen retrieval. Bitches from group I (GI) were operated on using a $5 \mathrm{~mm}$ a modular bipolar vessel-sealing device (LigaSure $^{\circledR}$ - Convidien Surgical Inc., São Paulo, SP, Brazil) and two $5 \mathrm{~mm}$ trocartes placed in each side, laterally to the midline, and a $10 \mathrm{~mm}$ midline port, placed cranially to the umbilicus. Group II (GII) was submitted to the same approach, though using a $10 \mathrm{~mm}$ trocarte placed on the right side instead of a $5 \mathrm{~mm}$ portal. Group III (GIII) was submitted to the same procedure and port placement employed on the GII; however, the ultrasonic shear (Autosonix ${ }^{\circledR}$ - Convidien Surgical Inc., São Paulo, SP, Brazil) was used for prophylactic hemostasis. The purpose of comparing $5 \mathrm{~mm}$ to $10 \mathrm{~mm}$ trocarte was to determinate if the shorter diameter trocarte is large enough to retreave the resected reproductive tract with no requirement for port incision enlargement.

A mixture of acepromazine $(0.05 \mathrm{mg} / \mathrm{kg})$ and tramadol chloride $(2 \mathrm{mg} / \mathrm{kg})$ was given intramuscularly. Anesthesia was induced 30 minutes following premedication, using intravenous bolus of sodium thiopental $(12.5 \mathrm{mg} / \mathrm{kg})$. Anesthesia was maintained using halothane vaporized in $100 \%$ oxygen, in a semiclosed circuit. Additionally, all animals received epidural lidocaine chloride $(6 \mathrm{mg} / \mathrm{kg})$ and ampicillin sodium $(20 \mathrm{mg} / \mathrm{kg})$ intravenously in the early pre-operative period. The same dose of antibiotic solution was given 8 hours following surgery.

The first trocarte was introduced into the preumbilical ventral midline using the open technique and a retractable trocarte blade. The patient was kept in dorsal recumbency without head tilting for insufflation of the peritoneal cavity using carbon dioxide $\left(1 \mathrm{~L} \mathrm{~min}^{-1}\right.$ flow rate, 
$12 \mathrm{mmHg}$ intra-abdominal pressure). The peritoneal cavity was inspected using a $0^{\circ} 10 \mathrm{~mm}$ endoscope. The auxiliary trocartes were inserted under video-assisted guidance. In all groups the trocartes were placed according to the principles of port triangulation (Freeman, 1999). The auxiliary lateral ports were inserted caudally to the camera port, approximately at the level of the umbilicus.

The uterine body was manipulated using atraumatic forceps. A transparietal suspension suture was carried out in order to attach the uterine body to the ventral abdominal wall and expose the uterine vessels adequately (Fig 1A). A 3-0 polyglycolic acid thread with a $3.6 \mathrm{~cm}$ curved needle was employed to perform the suspension suture on the most caudal part of either right or left uterine horns. Afterwards, the uterine body and vessels were sealed and transected immediately cranial to the cervix. LigaSure $^{\mathrm{TM}}$ (Fig 1B) was used in GI and GII and Autosonix $^{\mathrm{TM}}$ (Fig 1C) was employed in GIII.

The patient position was changed by tying the right thoracic limb along with the contralateral one, in order to promote a slight rotation of the thorax to the left side. Such maneuver aimed to improve the exposure of the right pedicle and move the viscera away from the coagulation site, as described in another study (Silva et al., 2011). In all groups the ovarian suspensory ligament and pedicles were sealed and transected following proper exposure (Fig 1D). The same maneuver was performed for the hemostasis of the opposite pedicle. In GIII, the frequency of the ultrasonic surgical generator was set to $55.5 \mathrm{KHz}$ previous to the procedure.

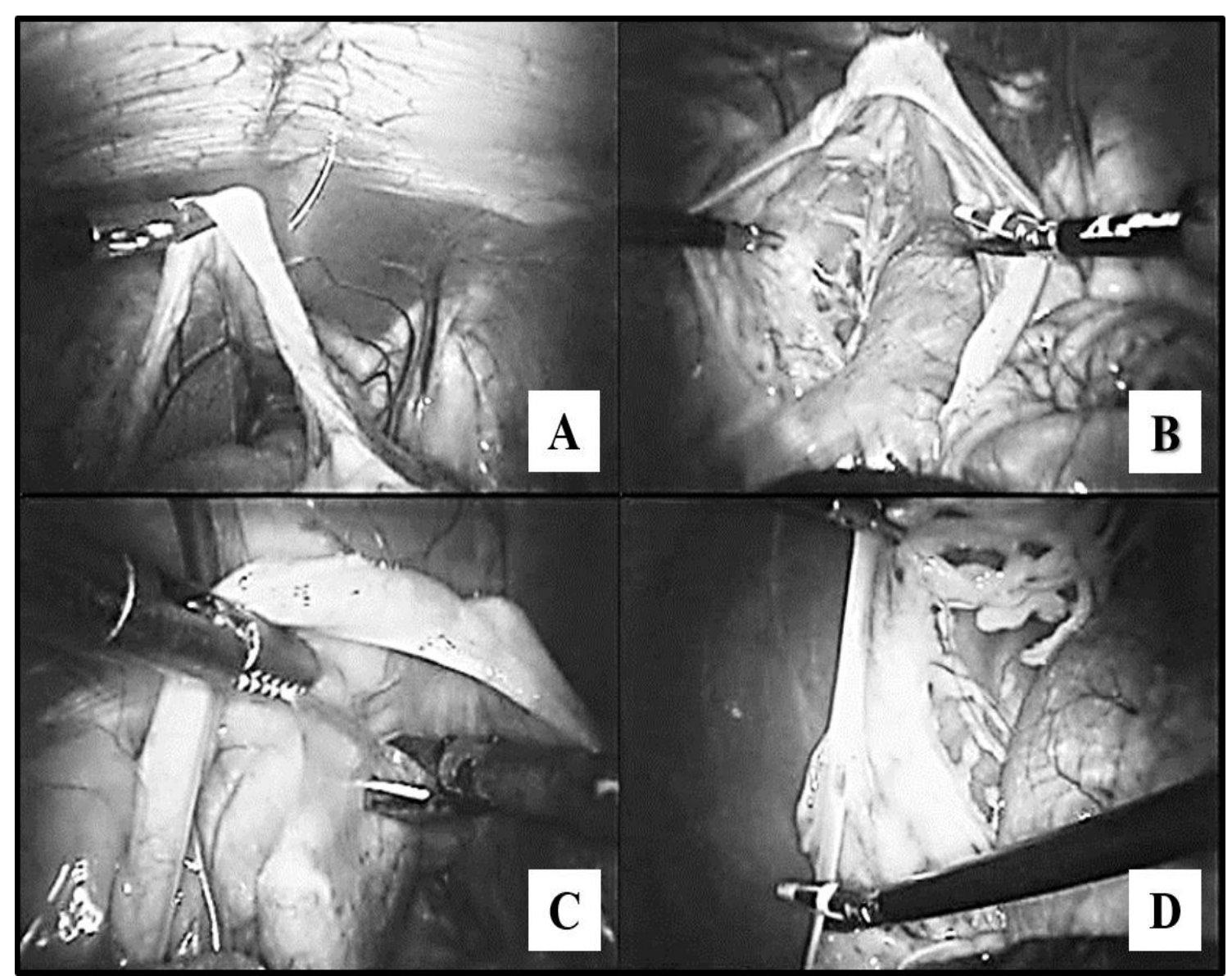

Figure 1. Diagram showing: transparietal suture on the right cranial to the uterine bifurcation, on the right uterine horn, for suspension of the uterus (A); localization of the uterine vessels for application of the LigaSure $^{\mathrm{TM}}(\mathrm{B})$; use of the Autosonix ${ }^{\mathrm{TM}}$ for prophylactic hemostasis (C); coagulation of the left ovarian pedicle using LigaSure ${ }^{\mathrm{TM}}$ (D). 
Blunt dissection of the mesometrium and uterine round ligament was performed after the transection of the ovarian pedicles on both sides. The frequency of bleeding during coagulation and transection of the uterine vessels and body, and ovarian pedicles, if present, would be recorded for further comparison among groups. Once the entire uterus was completely dissected, the surgical specimen was grasped and withdrawn from the abdominal cavity, following the retrieval of the right $5 \mathrm{~mm}$ trocarte in the animals in group GI. The incision would be enlarged if necessary in order to retrieve the surgical specimen adequately. In groups GII and GIII a 5-to-10 $\mathrm{mm}$ trocarte reducer was inserted through the $10 \mathrm{~mm}$ instrument trocarte in order to use a $5 \mathrm{~mm}$ grasping forceps for specimen retrieval, without leading to loss of pneumoperitoneum. The surgical specimen was then grasped and pulled into the $10 \mathrm{~mm}$ trocarte. Subsequently, the $10 \mathrm{~mm}$ trocarte was withdrawn from the abdomen along with the uterus and ovaries. Synthesis of the muscular layer was carried out using 2-0 nylon thread, in Sultan interrupted cross-pattern. The subcutaneous tissue was sutured using 3-0 nylon thread, in the same fashion employed for the muscular layer. The skin was sutured using 3-0 nylon thread, in simple interrupted pattern.

The animals were monitored for 12 hours following the surgical procedure. The patients were kept in individual cages, in a temperaturecontrolled environment. Tramadol chloride $(2 \mathrm{mg} / \mathrm{kg}, \mathrm{SC}, \mathrm{TID}$, for 4 days) and ketoprofen $(2 \mathrm{mg} / \mathrm{kg}, \mathrm{SC}, \mathrm{SID}$, for 3 days) were given. The wounds were cleansed using sterile normal saline three times a day, until suture removal, on the $10^{\text {th }}$ day post-op.

The intra-operative complications were classified into minor, intermediate and major. Minor complications included those that require no intervention, such as subcutaneous emphysema and organ or tissue damage without tearing or bleeding; intermediate complications were those that required laparoscopic intervention, with no need to convert to the open procedure, such as mild bleeding from the uterus or pedicles or due to damage to other organs or tissues; and major complications were considered as the lifethreatening conditions, which required interruption of the procedure and/or conversion for proper resolution, such as massive bleeding uncontrollable by laparoscopic approach, severe damage or tear to surrounding organs or tissues and anesthetic complications related to $\mathrm{CO}_{2}$ pneumoperitoneum.

The statistical analyses consisted of ANOVA and comparison of means using the Student's t-test for comparison of surgical time and patient weight among groups. The Chi-square test was used to assess the frequency of bleeding, complications and the need for port enlargement for specimen retrieval among groups. Technical difficulties encountered during surgery in all groups were assessed descriptively. A $p$-value below 0.05 was considered significant. The surgical complications were assessed descriptively.

\section{RESULTS}

There was no difference among groups regarding body weight and surgical time $(P>0.05)$. Body weight ranged from 8.0 to $18.9 \mathrm{~kg}( \pm 3.88 \mathrm{~kg})$ in GI, 6.1 and $16.0 \mathrm{~kg}( \pm 3.96 \mathrm{~kg})$ in GII and 6.0 and $14.7 \mathrm{~kg}( \pm 3.24 \mathrm{~kg})$ in GIII. The mean surgical time was $53.4 \pm 6.02$ minutes for GI, 64 \pm 19.19 minutes for GII and $49.4 \pm 11.24$ minutes for GIII.

Laparoscopic ovariohysterectomy in dogs using both devices for prophylactic hemostasis was perfectly feasible. There was no major complication in any of the groups. There were 18 intra-operative complications. Minor and intermediate complications occurred in $72.3 \%$ and $27.7 \%$ of all complications, respectively, regardless of the group (Table 1). Five out of all intra-operative complications $(27.7 \%)$ occurred in GI, all of them classified as minor; six $(33.3 \%)$ occurred in GII (three minor and three intermediate complications); and seven complications $(39.0 \%)$ occurred in GIII (five minor and two intermediate complications) $(p=0.7788)$.

There were two cases of subcutaneous emphysema adjacent to the trocarte sites, two lesions of the uterine horns with no bleeding during manipulation and one mechanical bladder serosa injury due to accidental clamping of the bladder wall with LigaSure ${ }^{\mathrm{TM}}$ during manipulation of the uterine vessels in GI. GII showed one case of portal site subcutaneous emphysema, two cases of trauma with no bleeding on the uterine horns during 
manipulation, two minor bleeding episodes in the ovarian pedicles, which were classified as intermediate lesions. There was one case of mild splenic bleeding caused by accidental puncture during laparoscopic-assisted insertion of an auxiliary trocarte, which was controlled by simple compression using a gauze swab.

Table 1. Distribution of frequencies of complications during 3-port laparoscopic ovariohysterectomy in bitches using LigaSure ${ }^{\mathrm{TM}}$ and $5 \mathrm{~mm}$ trocarte, LigaSure ${ }^{\mathrm{TM}}$ and $10 \mathrm{~mm}$ trocarte and Autosonix ${ }^{\mathrm{TM}}$ and $10 \mathrm{~mm}$ trocarte for retrieval of resected reproductive tract

\begin{tabular}{llllll}
\hline \multirow{2}{*}{ Severity } & \multirow{2}{*}{ Complications } & \multicolumn{2}{l}{ Frequency per group } & \multirow{2}{*}{ Overall } \\
\cline { 3 - 5 } & & GI & GII & GIII & \\
\hline \multirow{3}{*}{ Minor } & Subcutaneous emphysema & 2 & 1 & 4 & $7(38.9 \%)$ \\
& Trauma to uterine horn & 2 & 2 & 1 & $5(27.8 \%)$ \\
& Trauma to the bladder & 1 & - & & $1(5.6 \%)$ \\
\hline \multirow{3}{*}{ Intermediate } & Hemorrhage from the ovarian pedicle & - & 2 & - & $2(11.05 \%)$ \\
& Hemorrhage from spleen & - & 1 & 1 & $2(11.05 \%)$ \\
& Hemorrhage from uterine vessel & - & - & 1 & $1(5.6 \%)$ \\
\hline Major & - & - & - & - & - \\
\hline Overall & - & $5(27.8 \%)$ & $6(33.3 \%)$ & $7(39 \%)$ & $18(100 \%)$ \\
\hline
\end{tabular}

Minor complications in GIII included four cases of subcutaneous emphysemas and one case of trauma with no bleeding to the uterine horn during manipulation; intermediate complications were a case of puncture to the spleen with the Autosonix ${ }^{\mathrm{TM}}$ forceps during manipulation of the viscera, also treated with simple compression. There was a case of bleeding of the uterine vessels due to the application of ultrasonic energy on an incorrect site, thus producing inappropriate hemostasis of the uterine vessels. Such complication was managed by applying a new coagulation closely adjacent to the lesion site. Regarding technical difficulties, the bladder was filled in eight patients $(53.3 \%)$, which hindered the approach to the round ligament of the uterus in seven cases $(46.6 \%)$.

The major technical difficulty was the coagulation/resection of the uterine body, which required longer surgical time than the coagulation/resection of the pedicles. The $5 \mathrm{~mm}$ trocarte (GI) was not large enough to allow adequate retrieval of the uterus and ovaries. Port enlargement for retrieval of the uterus and ovaries was required in all patients in GI (100\%), while none of the dogs required port enlargement in both GII and GIII $(p=0.0006)$.

\section{DISCUSSION}

The approach to the uterus was initiated by the uterine vessels (Brun et al., 2000) and not by the ovarian pedicles as described in other studies involving laparoscopic (Davidson et al., 2004; Malm et al., 2004; Mayhew and Brown, 2007) and conventional approaches (Hedlund, 2007). The intra-operative modification of the positioning of the patient was another crucial maneuver. The attachment of both thoracic limbs together in a lateral position promoted mild rotation of the thorax as described in another trial (Silva et al., 2011). Consequently, surgical exposure of the ovarian pedicles was improved, although trauma to the uterine horns and bleeding from the ovarian pedicles occurred in five and two cases. Moreover, no head-down tilt was required, as performed in other studies (Hancock et al., 2005; Mayhew and Brown, 2007). The Trendelenburg positioning associated to the $\mathrm{CO}_{2}$ pneumoperitoneum induces respiratory stress, especially due to the increase of pressure on the diaphragm (Normando et al., 2004).

The two cases of bleeding from the ovarian pedicles were associated to the lack of experience of the surgeon with the sources of energy employed in the current study. Short exposure of the grasped tissue to the ultrasonic energy or exaggerate traction of the pedicle during coagulation could be the main reasons for that mild complication. Hemorrhage of the uterine vessels happened in one case due to incorrect application of the ultrasonic shears on the target tissue. Hemorrhage was also found in other studies and was also attributed to lack of experience of the surgeon (Malm et al., 2004; 
Hancock et al., 2005; Silva et al., 2011). Although laparoscopic spay may seem challenging for non-experienced surgeons, the learning curve can be reached with as little as 20 procedures, depending on the technique and instruments employed (Silva et al., 2011).

Injuries inflicted by inaccurate use of laparoscopic surgical instruments were reported by several authors (Brun et al., 2000; Hancock et al., 2005; Mayhew and Brown, 2007). In our study, iatrogenic injury to the spleen occurred during the insertion of an auxiliary trocarte in one patient (GII) and in another case, by the imprecise usage of the harmonic scalpel, which was previously reported in another trial (Mayhew and Brown, 2007). Regarding splenic injuries, several techniques can be used in order to manage bleeding, such as compression using gauze swab, argon plasma coagulation, suturing, and application of absorbable gelfoam hemostatic sponges or fibrin sealant (CanbyHagino et al., 2000).

In our study, bladder catheterization was not performed, which hindered the approach to the round ligament of the uterus. Therefore, we strongly recommend pre-operative bladder emptying. Regarding the transection of the round ligament, we suggest that scissors should be used instead of bipolar diathermy. The uterine round ligament is a thin and poorly vascularized tissue. Such tissue constitution provides low impedance for the application of bipolar energy. Thus, mechanical dissection of the round ligament is efficient and avoids the risk of energy-inflicted damage to the bladder and other surrounding tissues.

The mean overall surgical time obtained in our study differed from those reported by others (Davidson et al., 2004; Malm et al., 2004; Mayhew and Brown, 2007). The intra-corporal dissection of the broad ligament increased the surgical time in comparison to other studies in which such maneuver was not carried out (Mayhew and Brown, 2007; Silva et al., 2011). The learning curve also influences the surgical time (Malm et al., 2004; Silva et al., 2011). The injuries reported in our study were also associated to the lack of experience of the surgical team, which was highlighted by others (Mayhew and Brown, 2007). Such complications tend to become potentially rare as soon as the learning curve is reached.

The $5 \mathrm{~mm}$ trocarte was not adequate for retrieving the resected uterus and ovaries without need for enlargement of the port incision site. However, such technical difficulty did not affect surgical time in comparison to the use of $10 \mathrm{~mm}$ trocarte in groups GII and GIII. The need for port incision enlargement for specimen retrieval is expected in certain laparoscopic procedures such as nephrectomy (Brun et al., 2002) and OVH for pyometra (Adamovich-Rippe et al., 2013). However, regardless of the trocarte diameter or the need for port incision enlargement, laparoscopic surgery may still be considered minimally invasive in comparison to the conventional celiotomy approach (Freeman, 1999).

In conclusion, the harmonic scalpel and the modulated bipolar vessel-sealing device are appropriate for use as a single method of prophylactic hemostasis during 3-port total laparoscopic approach for elective OVH. The equipment and techniques tested did not differ and showed efficiency for spaying healthy bitches and those owning reproductive disorder.

\section{ACKNOWLEDGEMENTS}

The authors would like to thank Astus Medical Technology and Jomhedica Norte Medical Supply for the technical support, and the University of Passo Fundo for providing the academic facilities.

\section{REFERENCE}

ADAMOVICH-RIPPE， K.N.; MAYHEW， P.D.; RUNGE, J.J. et al. Evaluation of laparoscopic-assisted ovariohysterectomy for treatment of canine pyometra. Vet. Surg., v.42, p.572-578, 2013.

AUSTIN, B.; LANZ, O.I.; HAMILTON, S.M. et al. Laparoscopic ovariohysterectomy in nine dogs. J. Am. Anim. Hosp. Assoc., v.39, p.391-396, 2003.

BRUN, M.V.; BECK, C.A.C.; MARIANO, M.B. et al. Nefrectomia laparoscópica em cão parasitado por Dioctophyma renale - relato de caso. Arq. Cienc. Vet. Zoolog. Unipar, v.5, p.145-152, 2002.

BRUN, M.V.; SILVA FILHO, A.P.; BECK, C.A.C. et al. Laparoscopic ovariohysterectomy in canines. Braz. J. Vet. Res. Anim. Sci., v.37, p.480-485, 2000. 
BUBENIK, L.J.; HOSGOOD, G.; VASANJEE, S.C. et al. Bursting tension of medium and large canine arteries sealed with ultrasonic energy or suture ligation. Vet. Surg., v.34, p.289-293, 2005.

CANBY-HAGINO, E.D.; MOREY, A.F.; JATOI, I. et $a l$. Fibrin sealant treatment of splenic injury during open and laparoscopic left radical nephrectomy. $J$. Urol., v.164, p.2004-2005, 2000.

DAVIDSON, E.B.; MOLL, H.D.; PAYTON, M.E. et al. Comparison of laparoscopic ovariohysterectomy and ovariohysterectomy in dogs. Vet. Sug., v.33, p.6269, 2004.

DEVITT, C.M.; COX, R.E.; HAILEY, J.J. et al. Duration, complications, stress, and pain of open ovariohysterectomy versus a simple method of laparoscopic-assisted ovariohysterectomy in dogs. J.A.V.M.A., v.227, p.921-927, 2005.

FREEMAN, L.J. Minimally invasive surgery of the reproductive system. In: FREEMAN, L.J. (ed.). Veterinary Endosurgery. St. Louis: Mosby, 1999. pp. 105-117.

HANCOCK, R.B.; LANZ, O.I.; WALDRON, D.R. et al. Comparison of postoperative pain after ovariohysterectomy by harmonic scalpel-assisted laparoscopy compared with median celiotomy and ligation in dogs. Vet. Surg., v.34, p.273-282, 2005.
HEDLUND, C.S. Surgery of the reproductive and genital systems. In: FOSSUM, T.W.; HEDLUND, C.S.; JOHNSON, A.L. et al. (Eds.). Small animal surgery, 3.ed., Saint Louis: Mosby Elsevier. 2007. pp.702-774.

HOWE, L.M. Surgical methods of contraception and sterilization. Theriogenol., v.66, p.500-509, 2006.

MALM, C.; SAVASSI-ROCHA, P.R.; GHELLEN, V.A. et al. Ovariohysterectomy: experimental and comparative study between laparoscopic and conventional approaches. Intra-operative phase. Arq. Bras. Med. Vet. Zootec., v.56, p.457-466, 2004.

MAYHEW, P.D.; BROWN, D.C. Comparison of three techniques for ovarian pedicle hemostasis during laparoscopic-assisted ovariohysterectomy. Vet. Surg., v.36, p.541-547, 2007.

NORMANDO, V.M.F.; BRITO, M.V.H.; ARAÚJO JÚNIOR, F.A. et al. Respiratory repercussion of pneumoperitoneum induced in pigs. Acta Cir. Bras., v.19, p.664-669, 2004.

SILVA, M.A.M.; SANTOS-BATISTA, P.A.C.; POGIANNI, F.M. et al. Single-port video-assisted ovariohysterectomy in bitches: retrospective study of 20 cases. Cienc. Rural, v.41, p.294-300, 2011. 